\title{
Selection of Suitable Starter Cultures for Nutrient Composition Enhancement of Spent Sorghum Grains and Sweet Potato Leaves
}

\author{
I. A. Onyimba ${ }^{1}$, C. I. C. Ogbonna ${ }^{1}$, C. O. O. Chukwu ${ }^{2}$, \\ A. I. Ogbonna ${ }^{1}$, C. E. Odu ${ }^{3}$ and C. O. Akueshi ${ }^{1}$ \\ ${ }^{I}$ Dept. of Plant Science and Technology, University of Jos, Nigeria \\ ${ }^{2}$ Federal College of Veterinary and Medical Laboratory Technology, National Veterinary Research Institute, \\ Vom, Nigeria \\ ${ }^{3}$ Dept. of Biological Sciences, University of Maiduguri, Nigeria
}

\begin{abstract}
In an effort to find suitable starter cultures for enhancing the nutrient compositions of spent sorghum grains (SSG) and sweet potato leaves (SPL), three microorganisms, Aspergillus niger, Chaetomium globosum and Saccharomyces cerevisiae were used in singles and in combinations to ferment SSG and SPL for 21 days at a temperature of $25 \pm 2^{\circ} \mathrm{C}$. All the microbial treatments brought about increases in crude protein, crude fat and energy contents of both substrates, with accompanying reductions in crude fibre contents. SPL fermented with the combination of C. globosum and S. cerevisiae had the highest protein, fat and energy increases observed $(96 \%, 368 \%$ and $10.2 \%$ respectively). The combination of C. globosum and S. cerevisiae also caused the highest crude fibre reduction in SSG (33.86\%) while the combination of all three test organisms caused the highest crude fibre reduction in SPL (37.44\%). Ash content increased in most cases while nitrogen free extract (NFE) values generally declined. The consortium of the three test organisms was concluded to be the best starter culture for enhancing the nutrient composition of SSG while the combination of C. globosum and S. cerevisiae was best for SPL.
\end{abstract}

Keywords: nutrient composition, sorghum, spent grains, starter cultures, sweet potato leaves

\section{Introduction}

The high cost of conventional animal feeds has led animal nutritionists to search for cheaper alternative sources of feed for animals. Agricultural wastes and agro-industrial by-products represent vast utilizable resources. The agro-industrial by-product, brewery spent grains and the agricultural residue, sweet potato leaves, are obtainable in abundant quantities in Nigeria. For some time now these have been used as feedstuffs by animal farmers. The fibre content of these two feedstuffs is high and thus limits the extent to which they can be used in animal feeding, especially in the feeding of monogastric animals. It is desirable to increase the nutritive value of these fibrous feedstuffs. The role of microorganisms as tools for processing renewable organic resources has been appreciated and is reflected in their involvement in several bioconversion processes which have been shown to be practical [1\}. Microbial upgrading of solid wastes is becoming increasingly attractive in view of stricter environmental regulations and the unacceptability of alternative treatment methods [2]. Microorganisms vary in their bioconversion potentials depending on their enzymatic capabilities. The use of carefully selected starter cultures is essential to effective bioconversion. Starter cultures are said to reduce fermentation time as well as guarantee product quality [3]. The objective of this study was to determine the abilities of Aspergillus niger, Chaetomium globosum and Saccharomyces cerevisiae, in singles and in combinations, to enhance the nutritive value of brewery spent sorghum grains and sweet potato leaves with the view to selecting suitable starter cultures for possible upgrading of the by-products to animal feed.

\subsection{Sample collection}

\section{Materials And Methods}

Spent sorghum grains used in the work were obtained from Jos International Brewery while sweet potato leaves were obtained from sweet potato farms in Jos, Nigeria. Both samples were collected in clean polythene bags and taken to the laboratory where they were dried in an oven at $60{ }^{\circ} \mathrm{C}$. The leaf sample was pulverized, after which both samples were separately stored in dry clean plastic jars.

\subsection{Test organisms}

The test organisms Aspergillus niger, Chaetomium globosum and Saccharomyces cerevisiae were isolated from fermenting spent sorghum grains and sweet potato leaves in an earlier study. The fungi, A. niger and C. globosum were selected from among other fungal isolates based on their abilities to produce biopolymer degrading enzymes and their abilities to utilize the experimental substrates as sole sources of carbon and nitrogen. Saccharomyces. cerevisiae was selected for its known fermentative ability. 


\subsection{Experimental Procedure}

Twenty grammes of dried spent sorghum grains (SSG) was transferred into each of 21 conical flasks. Twenty grammes of dried pulverized sweet potato leaf (SPL) was transferred into another set of 21 flasks. The content of each flask was moistened with $35 \mathrm{ml}$ of water. A spatula was used to thoroughly mix the contents of the flasks. The mouth of each flask was fitted with an aeration apparatus which consisted of a rubber cork with two glass tubes running through its middle. The outer ends of the glass tubes were plugged with cotton wool and then covered with aluminium foil. The flasks, together with aeration apparatus, were autoclaved for 15 minutes at $121^{\circ} \mathrm{C}$ at $1 \mathrm{~kg} / \mathrm{cm}^{2}$, after which they were allowed to cool. The sterilized samples were inoculated using single and mixed cultures of the test organisms. Six different microbial combinations were used for the inoculation with triplicate replications made for each combination. Out of the 21 flasks set up for each fermentation sample, 18 were inoculated while 3 were not inoculated. The uninoculated flasks served as the controls. For single organism fermentation a $3 \mathrm{ml}$ volume of fungal spore or yeast cell suspension was used to inoculate the contents of each flask. In double organism fermentation $1.5 \mathrm{ml}$ each of the spore or cell suspension of both microorganisms were used to inoculate the samples. Where all the three selected microorganisms were used to inoculate a sample, $1 \mathrm{ml}$ of the suspension of each microorganism was used. Inoculation was done by spreading the inoculum all over the surface of the sample with the help of sterile pipettes. The inoculated samples were mixed thoroughly with a sterile spatula. This helped to ensure that the fungal spores and yeast cells were well distributed. The microbial combinations used and their concentrations were as given below:

(i) A alone (6.42 $10^{6} \quad$ spores) (ii) $\mathbf{C}$ alone (7.02 $\times 10^{6}$ spores) (iii) $\mathbf{A}\left(3.21 \times 10^{6}\right.$ spores $)+\mathbf{C}\left(3.51 \times 10^{6}\right.$ spores) (iv) $\mathbf{A}\left(3.21 \times 10^{6}\right.$ spores $+\mathbf{S}\left(3.96 \times 10^{6}\right.$ cells $)$ (v) $\mathbf{C}\left(3.51 \times 10^{6}\right.$ spores $+\mathbf{S}\left(3.96 \times 10^{6}\right.$ cells $)$ (vi) $\mathbf{A}$ $\left(2.14 \times 10^{6}\right.$ spores $)+\mathbf{C}\left(2.34 \times 10^{6}\right.$ spores $)+\mathbf{S}\left(3.96 \times 10^{6}\right.$ cells $)$

Where: $\quad \mathbf{A}=$ Aspergillus niger, $\mathbf{C}=$ Chaetomium globosum, $\mathbf{S}=$ Saccharomyces cerevisiae.

The pieces of foil paper were removed and fermentation was allowed to proceed aerobically for 21 days at $25 \pm 2^{\circ} \mathrm{C}$. After the fermentation period the samples were sterilized by tyndalization, dried in a hot air oven at $60{ }^{\circ} \mathrm{C}$, blended using a domestic dry blender and then stored in sterile air tight bottles. Proximate analyses of the fermented and non fermented samples were carried out using the method of [4]. Energy content of the substrates was assessed using recommended general conversion factors for food energy (4, 4, $9 \mathrm{kcal} / \mathrm{g}$ for protein, carbohydrate and fat respectively) [5]. The most suitable microbial combination was selected based on ability to enhance the crude protein and energy content of the substrate, and also the ability to effectively reduce the crude fibre content of the substrate. Statistical analysis of results obtained was carried out using Analysis of Variance at 5\% significance level [6]. LSD was used to separate means with significant differences.

\section{Results And Discussion}

Details of the effects of fermentation with the test organisms in singles and in combinations on the nutrient compositions of the substrates are presented in Tables 1 and 2. All the microbial treatments brought about significant increases $(\mathrm{P}<0.05)$ in crude protein, crude fat and energy contents, with accompanying reductions in the crude fibre contents of both substrates. The combination of A. niger, C. globosum and $S$. cerevisiae brought about the highest protein increase of $56 \%$ in the spent sorghum grains while the combination of C. globosum and S. cerevisiae brought about the highest protein increase (96\%) in the sweet potato leaves (SPL). These increases in crude protein content of the substrates were as a result of protein synthesis from simple substances by the microorganisms. The use of microorganisms particularly fungi for protein enrichment of organic substrates is well documented. The finding is comparable to that of [7] who reported protein enrichment of sweet potato as a result of solid state fermentation and that of Iyayi and Losel [8] who reported protein enrichment in cassava by-products through solid state fermentation by fungi. The protein contents of SSG fermented with the combination of A. niger, C. globosum and S. cerevisiae and SPL fermented with the coculture of C. globosum and S. cerevisiae are comparable to the high protein content ( 44 to $48 \%$ ) of soy meal feed, a widely used source of animal feed [9]. Thus, the use of these microbial combinations can significantly enhance the protein contents of SSG and SPL. This makes the fermented substrates to be good sources of protein for animal feed. The fat contents of the substrates increased from a range of $2.42-2.85 \%$ to a range of $3.48-9.05 \%$. C. globosum acting alone caused the highest fat increase of $217 \%$ in SSG and the combination of C. globosum and S. cerevisiae caused the highest increase of 368\% in SPL. Increase in fat content means increase in the energy contents of the substrates. 
Selection of Suitable Starter Cultures for Nutrient Composition Enhancement of Spent Sorghum

Table 1: Effects of Fermentation with the Test Microorganisms in Singles and in Combinations on the Nutrient Composition of Spent Sorghum Grains

\begin{tabular}{|c|c|c|c|c|c|c|c|}
\hline STARTERS & ${ }^{1} \mathrm{DM}$ & $\mathrm{CP}$ & $\mathrm{CF}$ & FAT & $\mathrm{ASH}$ & NFE & $\begin{array}{l}\text { ENERGY } \\
(\mathrm{kcal} / 100 \mathrm{~g})\end{array}$ \\
\hline Control & 93 & $27.85^{\mathrm{a}}$ & $24.19^{\mathrm{f}}$ & $2.85^{\mathrm{a}}$ & $6.30^{\mathrm{a}}$ & $38.81^{\mathrm{a}}$ & $292.29^{\mathrm{a}}$ \\
\hline Aspergillus. niger & 92 & $37.32^{\mathrm{b}}$ & $18.05^{\mathrm{b}}$ & $3.70^{\mathrm{b}}$ & $8.40^{\mathrm{b}}$ & $32.53^{\mathrm{b}}$ & $312.78^{d}$ \\
\hline Chaetomium globosum & 91 & $38.75^{\mathrm{c}}$ & $20.58^{\mathrm{d}}$ & $9.05^{\mathrm{g}}$ & $12.30^{\mathrm{cd}}$ & $19.32^{\mathrm{d}}$ & $313.73^{\mathrm{d}}$ \\
\hline A. niger + C. globosum & 91 & $40.79^{\mathrm{d}}$ & $16.00^{\mathrm{a}}$ & $6.67^{\mathrm{d}}$ & $15.80^{\circ}$ & $20.74^{d}$ & $306.15^{\mathrm{c}}$ \\
\hline $\begin{array}{l}\text { A. niger }+ \text { Saccharomyces } \\
\text { cerevisiae }\end{array}$ & 92 & $41.39^{\mathrm{e}}$ & $18.93^{\mathrm{c}}$ & $7.14^{\mathrm{e}}$ & $11.80^{\mathrm{c}}$ & $20.74^{\mathrm{d}}$ & $312.78^{d}$ \\
\hline $\begin{array}{l}\text { C. globosum }+ \\
\text { S. cerevisiae }\end{array}$ & 91 & $41.80^{\mathrm{f}}$ & $21.98^{\mathrm{e}}$ & $7.69^{\mathrm{f}}$ & $12.50^{\mathrm{d}}$ & $16.03^{\mathrm{e}}$ & $300.53^{\mathrm{b}}$ \\
\hline $\begin{array}{l}\text { A. niger }+C . \text { globosum } \\
+ \text { S. cerevisiae }\end{array}$ & 92 & $43.51^{\mathrm{g}}$ & $18.18^{\mathrm{b}}$ & $4.55^{\mathrm{c}}$ & $8.70^{\mathrm{b}}$ & $25.06^{\mathrm{c}}$ & $315.23^{\mathrm{d}}$ \\
\hline
\end{tabular}

Table 2: Effects of Fermentation with the Test Microorganisms in Singles and in Combinations on the Nutrient Composition of Sweet Potato Leaves

\begin{tabular}{|c|c|c|c|c|c|c|c|}
\hline STARTERS & $\mathrm{DM}$ & $\mathrm{CP}$ & $\mathrm{CF}$ & FAT & $\mathrm{ASH}$ & NFE & $\begin{array}{l}\text { ENERGY } \\
(\mathrm{kcal} / 100 \mathrm{~g})\end{array}$ \\
\hline Control & 92 & $20.45^{\mathrm{a}}$ & $25.24^{\mathrm{a}}$ & $2.42^{\mathrm{a}}$ & $15.30^{\mathrm{a}}$ & $36.59^{\mathrm{a}}$ & $269.94^{\mathrm{a}}$ \\
\hline Aspergillus. niger & 90 & $34.77^{\mathrm{b}}$ & $18.79^{\mathrm{b}}$ & $3.48^{\mathrm{b}}$ & $12.40^{\mathrm{b}}$ & $30.56^{\mathrm{b}}$ & $292.64^{d}$ \\
\hline Chaetomium globosum & 91 & $40.03^{d}$ & $19.43^{\mathrm{b}}$ & $5.67^{\mathrm{d}}$ & $13.40^{\mathrm{c}}$ & $21.47^{\mathrm{d}}$ & $297.03^{\mathrm{e}}$ \\
\hline A. niger $+C$. globosum & 90 & $38.64^{\mathrm{c}}$ & $18.76^{\mathrm{b}}$ & $3.57^{\mathrm{b}}$ & $17.20^{\mathrm{d}}$ & $21.83^{\mathrm{d}}$ & $274.01^{\mathrm{b}}$ \\
\hline $\begin{array}{l}\text { A. niger }+ \text { Saccharomyces } \\
\text { cerevisiae }\end{array}$ & 89 & $40.12^{\mathrm{d}}$ & $19.03^{\mathrm{b}}$ & $4.05^{\mathrm{c}}$ & $16.70^{\mathrm{d}}$ & $20.10^{\mathrm{e}}$ & $277.33^{\mathrm{b}}$ \\
\hline $\begin{array}{l}\text { C. globosum + } \\
\text { S. cerevisiae }\end{array}$ & 91 & $40.19^{d}$ & $19.35^{\mathrm{b}}$ & $8.92^{\mathrm{e}}$ & $17.40^{\circ}$ & $14.14^{\mathrm{f}}$ & $297.60^{\mathrm{e}}$ \\
\hline $\begin{array}{l}\text { A. niger }+ \text { C. globosum } \\
+ \text { S. cerevisiae }\end{array}$ & 91 & $38.85^{\mathrm{c}}$ & $15.79^{\mathrm{c}}$ & $3.51^{\mathrm{b}}$ & $17.40^{\circ}$ & $24.45^{\mathrm{c}}$ & $284.79^{\mathrm{c}}$ \\
\hline
\end{tabular}

Figures in the same column having different superscripts are significantly different $(\mathrm{P}=0.05)$

The fat contents of the fermented substrates were, in most cases, found to be within the range required by rats and mice [10], and also within the requirement of chicken of different types and ages [11]. Crude fibre was effectively reduced by the six different microbial treatments in both substrates from a range of 24.19$25.24 \%$ to a range of $15.79-21.98 \%$.Crude fibre was best reduced (33.86\%) in SSG by the combination of $A$. niger and C. globosum while the combination of A. niger, C. globosum and S. cerevisiae caused the highest reduction in SPL (37.44\%). The reductions of the crude fibre contents of the substrates were probably due to cellulolytic activities of $A$. niger and C. globosum. Degradation of cellulose by these fungi has been documented by several authors ([12]; [13] and [14]). A. niger and C. globosum could have broken down the cellulose and also the hemicellulose fractions of the substrates into simple sugars. Though a certain level of crude fibre is required in the diet of animals, high crude fibre content remains a limiting factor in the use of agricultural residues and agro-industrial by-products (including SSG and SPL) in animal feeding. This reduction in the crude fibre content of SSG and SPL is, therefore, desirable and might have increased the nutritive value of 
the substrates especially for monogastric animals. Highest energy increase (7.8\%) in SSG was brought about by the combination of A. niger, C. globosum and S. cerevisiae while the combination of $C$. globosum and $S$. cerevisiae caused the highest increase of $10.2 \%$ in SPL. Ash content was found to increase in most cases. This may imply increases in the values of some of the elemental components of the substrates. These increases might have resulted from depletion of the organic matter content of the substrates as a result of microbial activity. There was a general decline in NFE values. The lower NFE values obtained were probably due to conversion of simple sugars from crude fibre breakdown into products like protein and fat.

\section{Conclusion}

The nutrient composition of spent sorghum grains and sweet potato leaves can be enhanced using selected combinations of A. niger, C. globosum and S. cerevisiae. Fermentation of the grains and leaves with the selected starter cultures increases the nutritive value of the substrates and as such increases their potential for use as animal feed. The consortium of A. niger, C. globosum and S. cerevisiae is recommended as a suitable starter culture for nutrient composition enhancement of spent sorghum grains while the combination of $C$. globosum and S. cerevisiae is recommended as a suitable starter culture for enhancement of the nutrient composition of sweet potato leaves.

\section{References}

[1] T. K.. Tan, and W. F. Leong, Screening for extracellular enzymes of fungi from manufacturing wastes, MIRCEN Journal 2, 1986, 445-452.

[2] M.A.P. Saquido, V.A. Cayabyab and F.R.Uyenco, The Use of Organic Residues in Rural Communities, (Tokyo: United Nations University, 1983)

[3] O.K. Achi, Traditional fermented protein condiments in Nigeria, African Journal of Biotechnology. 11, 2005, $511-517$.

[4] Association of Official Analytical Chemists (AOAC), Official methods of analysis (Arlington: AOAC, 1980).

[5] Food and Agricultural Organisation, Food energy - methods of analysis and conversion factors (Rome: Food and Agricultural Organisation of the United Nations, 2003)..

[6] J. H. Zar,. Biostatistical analysis, (Englewood Cliffs, NJ: Prentice Hall, 1974).

[7] O. A. Abu, Biochemical characteristics and utilization of processed sweet potato - Ipomoea batatas (L.) LAM for rabbit feeding, doctoral thesis, University of Ibadan, Ibadan, Nigeria, 1997.

[8] E. A. Iyayi and D. M. Losel, Protein enrichment of cassava by-products through solid state fermentation by fungi, The Journal of Food Technology in Africa, 2001, 6(4), 116-118.

[9] G. L. Cromwell, Soybean meal - "the gold standard" ( http://www.uky. edu/Ag/AnimalSciences/pubs/soybeanmeal-thegold standard.PDF, 1999)

[10] Institute for Laboratory Animal Research, Nutrient Requirements of Laboratory Animals, (Washington D. C.: National Academies Press, 1995).

[11] L. G. G. Chinke, Some agricultural investment opportunities in Nigeria (A practical Guide), (Jos: Chinke Lenke Publishers, 2000).

[12] Y. W. Han, Microbial utilization of straw, Advances in Applied Microbiology, 1978, 25, 119-153.

[13] C. I. C. Ogbonna, The effects of Nigerian fungi on Nigerian wood, doctoral thesis, University of Technology, Aston, Birmingham, 1980 .

[14] I. A. Onyimba, The Abilities of Selected Species of Microorganisms to Upgrade Spent Sorghum Grains and Sweet Potato Leaves for Use as Feed and in the Production of Composite Feed, doctoral thesis, University of Jos, Jos, Nigeria, 2013. 